\title{
Characterization and Classification of Turkish Wines Based on Elemental Composition
}

\author{
Ilknur Sen ${ }^{1}$ and Figen Tokatli ${ }^{1 *}$
}

\begin{abstract}
Commercial wines from 13 native and nonnative varieties in Turkey were analyzed for their elemental composition. Wines from four vintages (2006-2009) were analyzed by inductively coupled plasma with atomic emission spectrometry and mass spectroscopy (ICP-AES and ICP-MS) followed by multivariate statistics to study vintage, varietal, and regional differences. According to the partial least squares-discriminant analysis, wines from western regions could be discriminated with their higher $\mathrm{Pb}$ content. The red wines of two native grapes, Boğazkere and Öküzgözü, were separated from the remaining varieties based on their high $\mathrm{Ca}$ and low B and $\mathrm{Cu}$ levels. Öküzgözü wines were different from Syrah and Cabernet Sauvignon wines. Similarly, native Emir wines showed differences from Muscat wines. The effective variables for discrimination analysis were natural minerals $(\mathrm{Sr}, \mathrm{Li}$, $\mathrm{Al}, \mathrm{Ba}$, and $\mathrm{B})$ and minerals originating from agricultural activities, processing, or pollution $(\mathrm{Ca}, \mathrm{Cu}, \mathrm{Mg}, \mathrm{Co}, \mathrm{Pb}$, and $\mathrm{Ni}$ ). Characteristics of Turkish wines from native and nonnative grape varieties such as Cabernet Sauvignon, Merlot, Syrah, and Chardonnay were defined in terms of their mineral content for the first time.
\end{abstract}

Key words: geographical classification, grape variety, mineral content, multivariate analysis, wine

The chemical composition and sensory characteristics of wine are highly influenced by geographical origin, grape variety, climatic, vintage, and processing conditions (Marini et al. 2006). In addition to details on wine composition and nutritional value, many wine consumers now expect information on the original territory of wine products, as the geographical origin of a wine can be an important criterion ensuring the quality of product. The label "controlled denomination of origin" indicates recognized winegrowing regions, winemaking practices, and grapes (Martinez-Carrasco et al. 2005) and has been used in many wine-producing countries. The label may appear in different forms, such as denominazione di origine controllata (DOC), appellation d'origine contrôlée (AOC), and denominación de origen (DO) (Castro et al. 2011, Gonzalves et al. 2008, Marengo and Aceto 2003, Martin et al. 2012, Saavedra et al. 2011, Trujillo et al. 2011). The labeling of controlled denomination of origin can help to prevent fraud and protect the origin and quality of the wine.

The minerals in wine originate from the capacity of the vine to take elements from soil (geographical region), climatic factors such as heavy rains, environmental conditions such as pollution, and agricultural applications such as fertilizers and

${ }^{1}$ Izmir Institute of Technology, Department of Food Engineering, Urla-Izmir, TR35430, Turkey.

*Corresponding author (figentokatli@iyte.edu.tr; tel: +90 232750 6295; fax: +90232 750 6196)

Acknowledgments: This research was funded by the Scientific Research Project of Izmir Institute of Technology (IYTE-BAP-18-2008). The authors thank the Environmental Research Centre of Izmir Institute of Technology for the ICP-MS analyses.

Supplemental data is freely available with the online version of this article.

Manuscript submitted Jun 2013, revised Oct 2013, accepted Nov 2013

Copyright $(\subset 2014$ by the American Society for Enology and Viticulture. All rights reserved.

doi: 10.5344/ajev.2013.13081 pesticides. The mineral content of red and white wines from the same region can differ due to the impact of the vinification process on the elemental composition, such as the maceration step in red winemaking, where the juice is in longer contact with the skins and flesh of the grapes (Coetzee et al. 2005).

The elemental composition of wine has been useful in characterizing wine samples, identifying wine origin, and assessing the nutritional safety of the product (Fabani et al. 2010, Grindlay et al. 2008, Gonzalves et al. 2009). The latter highly depends on the capacity of vine to uptake toxic elements, which are the consequence of pollution in the soil. Heavy metals, especially lead $(\mathrm{Pb})$, cadmium $(\mathrm{Cd})$, and mercury (Hg), are toxic to humans (Volpe et al. 2009).

Previous studies on wine determined the elemental composition using inductively coupled plasma-atomic emission spectroscopy (ICP-AES) and mass spectrometry (ICP-MS), as well as graphite furnace atomic absorption spectrometry (GFAAS), flame atomic absorption spectrometry techniques (FAAS), and voltammetry. Wines from many countries have been successfully discriminated according to geographical region using elemental profiling (Angus et al. 2006, Etievant et al. 1988, Fabani et al. 2010, Gomez et al. 2004, Gonzalves et al. 2008, Kment et al. 2005, Moreno et al. 2007, Sperkova and Suchanek 2005, Thiel et al. 2004, Trujillo et al. 2011, Zou et al. 2012). To our knowledge, there are no published reports on the detailed elemental compositions and the classification of Turkish wines using multivariate statistical techniques. The classification of wine samples using multielement content is possible with the use of chemometric tools. Techniques such as principal component analyses (PCA), discriminant analyses (DA), and cluster analysis can be useful in the differentiation of samples according to their geographical origin, harvest year, and grape variety as well as the contribution of each variable to the established models.

Turkey has a long history of grapegrowing, and according to an OIV report on world vitiviniculture (OIV 2013), it had 
the fifth largest vineyard area of all wine-producing countries. The aim of this study was to characterize and classify monovarietal wine samples from grape varieties grown in Turkey based on their multielement composition and according to the geographic regions and grape varieties using multivariate statistical techniques. Significant elements that affected regional and varietal discrimination were also investigated.

\section{Materials and Methods}

Wine samples. A total of 116 commercial wine samples from the 2006, 2007, 2008, and 2009 harvest years were collected from local markets and included 66 red, five rosé, and 45 white wines. These wines were produced from 13 different grape varieties in Turkey, eight of which were native (Boğazkere, Öküzgözü, Çalkarası, Kalecik karası, Emir,
Narince, Sultaniye and Papazkarası) and five of which were nonnative (Cabernet Sauvignon, Merlot, Syrah, Muscat, and Chardonnay) (Table 1). Information on vineyard and grape variety of the samples was based on the information given on the wine bottles. The grape varieties were cultivated in 10 different regions from three areas of Turkey (Figure 1). All native varieties in this study are used for winemaking. Among them Sultaniye (or Sultani, a seedless white grape) is also used for raisin production and fresh consumption.

Reagents. $\mathrm{HNO}_{3}$ (suprapur 65\%), $\mathrm{H}_{2} \mathrm{O}_{2}$ (suprapur 30\%), multielement standard solution, and rhodium (Rh) were purchased from Merck (Darmstadt, Germany). Multielement standard solution of aluminum (Al), boron $(\mathrm{B})$, barium $(\mathrm{Ba})$, beryllium $(\mathrm{Be})$, bismuth $(\mathrm{Bi})$, calcium $(\mathrm{Ca})$, cadmium $(\mathrm{Cd})$, cobalt $(\mathrm{Co})$, chromium $(\mathrm{Cr})$, copper $(\mathrm{Cu})$, iron $(\mathrm{Fe})$, gallium

\begin{tabular}{|c|c|c|c|c|}
\hline Varietal & Area & Region & Vintage year & Samples (n) \\
\hline \multicolumn{5}{|l|}{ Red and rosé } \\
\hline Boğazkere & Eastern & Diyarbakır & 2007, 2008, 2009 & 5 \\
\hline Boğazkere & Central & Cappadocia & 2006,2008 & 2 \\
\hline Boğazkere & Central & Tokat & 2007 & 1 \\
\hline Cabernet Sauvignon & Western & Izmir & 2006, 2007 & 2 \\
\hline Cabernet Sauvignon & Western & Bozcaada & 2007 & 1 \\
\hline Cabernet Sauvignon & Western & Thrace & 2006, 2008 & 2 \\
\hline Cabernet Sauvignon & Central & Cappadocia & 2007, 2008 & 2 \\
\hline Cabernet Sauvignon & Central & Tokat & 2007 & 1 \\
\hline Çalkarası (red) & Western & Denizli & 2008 & 1 \\
\hline Çalkarası (rosé) & Western & Denizli & 2006, 2008, 2009 & 5 \\
\hline Kalecik Karası & Western & Denizli & $2006,2007,2008$ & 10 \\
\hline Kalecik Karası & Western & Izmir & 2006 & 1 \\
\hline Kalecik Karası & Western & Thrace & 2006 & 1 \\
\hline Kalecik Karası & Central & Ankara & $2006,2007,2008$ & 3 \\
\hline Merlot & Western & Denizli & 2006, 2007, 2008 & 4 \\
\hline Merlot & Western & Izmir & 2006, 2007, 2009 & 4 \\
\hline Merlot & Western & Thrace & 2007, 2008 & 2 \\
\hline Öküzgözü & Eastern & Elazığ & 2006, 2007, 2008, 2009 & 9 \\
\hline Öküzgözü & Central & Cappadocia & 2006 & 1 \\
\hline Öküzgözü & Central & Tokat & 2007 & 1 \\
\hline Papazkarası & Western & Thrace & 2006 & 1 \\
\hline Syrah & Western & Denizli & 2006, 2007, 2008, 2009 & 10 \\
\hline Syrah & Western & Manisa & 2008, 2009 & 2 \\
\hline \multicolumn{5}{|l|}{ White } \\
\hline Emir & Central & Cappadocia & $2006,2007,2008,0909$ & 10 \\
\hline Muscat & Western & Denizli & 2006, 2007, 2008, 2009 & 5 \\
\hline Muscat & Western & Izmir & 2006, 2008, 2009 & 4 \\
\hline Muscat & Western & Thrace & 2006 & 1 \\
\hline Muscat & Western & Manisa & 2008 & 1 \\
\hline Narince & Central & Tokat & $2006,2007,2008$ & 5 \\
\hline Narince & Western & Denizli & 2006 & 1 \\
\hline Narince & Western & Manisa & 2008, 2009 & 2 \\
\hline Sultaniye & Western & Denizli & 2006, 2007, 2008 & 5 \\
\hline Sultaniye & Western & Manisa & 2006 & 1 \\
\hline Chardonnay & Western & Denizli & 2006, 2007, 2009 & 3 \\
\hline Chardonnay & Western & Izmir & 2007, 2008, 2009 & 4 \\
\hline Chardonnay & Western & Thrace & 2006, 2007 & 2 \\
\hline Chardonnay & Central & Cappadocia & 2008 & 1 \\
\hline
\end{tabular}


(Ga), potassium (K), lithium (Li), magnesium ( $\mathrm{Mg}$ ), manganese $(\mathrm{Mn})$, sodium $(\mathrm{Na})$, nickel $(\mathrm{Ni})$, lead $(\mathrm{Pb})$, selenium $(\mathrm{Se})$, strontium (Sr), tellurium (Te), thallium (Tl), and zinc ( $\mathrm{Zn})(100$ $\mathrm{mg} / \mathrm{L})$ was dissolved in $1 \% \mathrm{HNO}_{3}(\mathrm{v} / \mathrm{v})$ for external calibration. For ICP-MS analyses, Rh was used as internal standard. The tuning solution of ICP-MS was $1 \mathrm{mg} / \mathrm{L} \mathrm{Li}$, yttrium (Y), $\mathrm{Co}, \mathrm{Tl}$, and cerium (Ce) mixture (Agilent Technologies, Santa Clara, CA). A certified reference wine sample including $\mathrm{Cd}$ and $\mathrm{Pb}$ was used for the accuracy of ICP-MS analyses (T0777, FAPAS, York, UK).

Instrumentation. The ICP-MS instrument was an Agilent 7500 ce ORS, equipped with a concentric nebulizer, nickel sampling cone, and peristaltic pump (Agilent Technologies). The octopole reaction system (ORS) used in the ICP-MS was FoodORS (library for food analysis) for the wine samples. Helium and no gas ORS modes were used in the method. The ICP-AES instrument was a Varian Liberty Series II with axial viewing plasma type (Varian Inc., Palo Alto, CA) and was used to quantify major elements such as $\mathrm{Na}, \mathrm{Mg}, \mathrm{K}, \mathrm{Ca}$, and Fe. Optimization parameters and operating conditions of ICP-MS and ICP-AES are given (Table 2).

Standards and spikes. The ICP-MS working standard solutions were prepared daily from stock solution using $1 \%$ $\mathrm{HNO}_{3}$ solution. The calibration concentrations (19 points) ranged from 0.01 to $500 \mu \mathrm{g} / \mathrm{L}$. Rh was used as internal standard in each ICP-MS working standard solution, wine sample, and spiked sample at a concentration of $10 \mu \mathrm{g} / \mathrm{L}$ in final solution. Spiked samples were also studied each time the digestion procedure was run. Trace elements like $\mathrm{Be}, \mathrm{Co}, \mathrm{Ga}, \mathrm{Cd}$, and $\mathrm{Tl}$ were spiked at a concentration of $2 \mu \mathrm{g} / \mathrm{L}$. $\mathrm{Li}, \mathrm{Pb}, \mathrm{Cr}$, and Ni were spiked at a concentration of $10 \mu \mathrm{g} / \mathrm{L}$. Two spike concentrations (100 and $1000 \mu \mathrm{g} / \mathrm{L}$ ) were used for B, Al, Mn, $\mathrm{Cu}, \mathrm{Zn}, \mathrm{Sr}$, and $\mathrm{Ba}$, which were present in wine at wider concentration ranges. The eight working standard solutions of ICP-AES (ranging from 0.3 to $60 \mathrm{mg} / \mathrm{L}$ ) were prepared from the multielement standard using $1 \% \mathrm{HNO}_{3}$ solution with an external calibration technique. Major elements like $\mathrm{Na}, \mathrm{Mg}$, $\mathrm{K}, \mathrm{Ca}$, and $\mathrm{Fe}$ were spiked at 1 and $10 \mathrm{mg} / \mathrm{L}$ concentrations.

Sample preparation. The neck of wine bottles was cleaned with $2 \% \mathrm{HNO}_{3}$ solution before opening to prevent contamination by trace metals. Once opened, bottles were

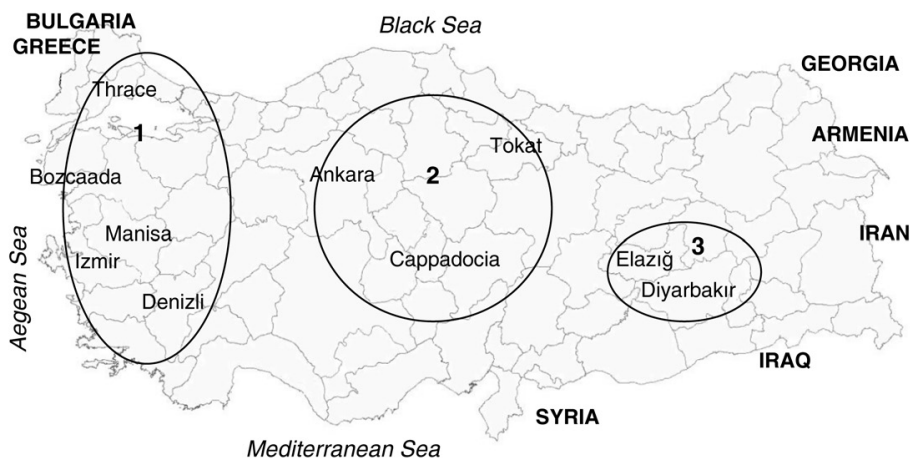

Figure 1 Wine regions in Turkey: (1) western Anatolia (Izmir, Manisa, Bozcaada, Thrace, Denizli); (2) central Anatolia (Ankara, Cappadocia, Tokat); and (3) eastern Anatolia (Diyarbakır, Elaziğ). treated according to a procedure based on the wet digestion of organic material in an open vessel (Skurikhin 1993). Rh was added as internal standard (ISTD). The solution with ISTD and $10 \mathrm{~mL} \mathrm{HNO}_{3}$ was heated until it evaporated down to a

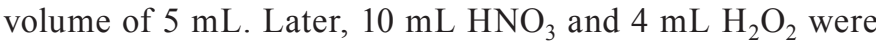
added. The heating process proceeded to a final volume of $5 \mathrm{~mL}$. The next step was the addition of $5 \mathrm{~mL} \mathrm{HNO}_{3}, 2 \mathrm{~mL}$ $\mathrm{H}_{2} \mathrm{O}_{2}$, and $10 \mathrm{~mL}$ ultrapure water and digestion of sample until the white fume was diminished. Eventually, the solution was diluted to a final volume of $100 \mathrm{~mL}$ with ultrapure water. The samples were kept at $4^{\circ} \mathrm{C}$ for 48 hours. The certified reference wine sample was treated in the same way as the wine samples. Two replicate digestions were made for each sample together with two blanks for every experiment set excluding the sample. The spiked samples were also prepared in an identical way following spiking.

Statistical analyses and method validation. The repeatability was evaluated by calculating the relative standard deviation of replicate measurements. The limit of detection

\begin{tabular}{ll}
\hline \multicolumn{1}{c}{ Table 2 ICP-MS and ICP-AES operational parameters. } \\
\hline Parameter & Value \\
\hline ICP-MS & \\
RF power & $1550 \mathrm{~W}$ \\
Sampling depth & $8-9 \mathrm{~mm}$ \\
Gas & Argon \\
Carrier gas flow & $0.9 \mathrm{~L} / \mathrm{min}$ \\
Make-up gas flow & $0.15-0.19 \mathrm{~L} / \mathrm{min}$ \\
Nebulizer pump & $0.1 \mathrm{rps}$ \\
Octopole reaction system & FoodORS \\
Interference equation & $208 \mathrm{~Pb}={ }^{208} \mathrm{~Pb}+{ }^{206} \mathrm{~Pb}+{ }^{207} \mathrm{~Pb}$ \\
Sample and skimmer cones & Nickel \\
Nebulizer & Concentric \\
Spray chamber temperature & $2{ }^{\circ} \mathrm{C}$ \\
Reaction/collision & \\
He gas flow & $4 \mathrm{~mL} / \mathrm{min}$ \\
Signal measurement & \\
Acquisition mode & Spectrum multitune \\
Acquisition time & $174 \mathrm{sec}$ \\
Calibration & External \\
Internal standard & $103 \mathrm{Rh}$ \\
Repetition & 3 \\
Stabilization time & $30 \mathrm{sec}$ \\
ICP-AES & \\
Power & $1.2 \mathrm{~kW}$ \\
PMT voltage & $650 \mathrm{~V}$ \\
Gas & Argon \\
Plasma gas & $15 \mathrm{~L} / \mathrm{min}$ \\
Auxiliary gas & $1.5 \mathrm{~L} / \mathrm{min}$ \\
Nebulizer & Concentric \\
Pump rate & $15 \mathrm{rpm}$ \\
Fast pump & On \\
Rinse time & \\
Sample uptake & \\
Integration time & \\
Replicates & \\
Calibration & \\
\hline
\end{tabular}


(LOD) was calculated as three times the standard deviation of the signal of the blank sample (prepared 10 times). The limit of quantification (LOQ) was calculated as 10 times the standard deviation of the signal of the blank sample. Recoveries were calculated based on the difference of spiked and unspiked samples and by taking the ratio of this difference to the assigned value. In general, relative standard deviation $<15 \%$ was obtained for the most variables. The elements with high relative standard deviations, such as $\mathrm{Be}, \mathrm{Ga}$, and $\mathrm{Tl}$, were eliminated from data analysis (although reported in tables).

All data were standardized by subtracting the averages and dividing with the standard deviations. Transformation was used on the variables to minimize skewness. The statistical analysis for some samples having values below the LOD was performed by assigning the corresponding LOD value. The data were statistically evaluated by multivariate statistical analysis using Simca-P (ver. 10.5; Umetrics Inc., Umea, Sweden) and Minitab (ver. 16; Minitab Inc., State College, PA). Principal component analysis (PCA), partial least squares-discriminant analysis (PLS-DA), and hierarchical cluster analysis (HCA) were used to evaluate the effect of growing region and grape variety on wine mineral properties. With PLS-DA, $\sim 80 \%$ of the data set was chosen for model development and the remaining $20 \%$ constituted the validation set. The model fit and cross-validation statistics of PLS-DA were given in terms of regression coefficients $\mathrm{R}_{\mathrm{Y}}^{2}$ and $\mathrm{Q}^{2}$, respectively. The significant variables affecting the models were determined with the variable importance plots (VIP) of PLS-DA models created by Simca software. The variables with a VIP $>1.0$ were taken as the significant ones in the model (Eriksson et al. 2001).

\section{Results}

The element concentrations of monovarietal red, rosé, and white wine samples are reported (Table 3, Table 4). The following elements were quantified in the samples: $\mathrm{Al}, \mathrm{B}, \mathrm{Ba}$, $\mathrm{Be}, \mathrm{Ca}, \mathrm{Cd}, \mathrm{Co}, \mathrm{Cr}, \mathrm{Cu}, \mathrm{Fe}, \mathrm{Ga}, \mathrm{K}, \mathrm{Li}, \mathrm{Mg}, \mathrm{Mn}, \mathrm{Na}, \mathrm{Ni}, \mathrm{Pb}$, $\mathrm{Sr}, \mathrm{Tl}$, and $\mathrm{Zn}$. The results and recovery (\%) values of the certified reference wine sample (contained $69.3 \mathrm{ng} / \mathrm{mL} \mathrm{Cd}$ and $260 \mathrm{ng} / \mathrm{mL} \mathrm{Pb}$ element) were $62.01 \% \pm 9.78$ and $89 \% \pm$ 14 for $\mathrm{Cd}$ and $280.29 \% \pm 29.36$ and $108 \% \pm 11$ for $\mathrm{Pb}$. The recovery values of spiked samples ranged from 77 to $120 \%$ for all elements except $\mathrm{K}$ and $\mathrm{Zn}(<60 \%$ in red wines). $\mathrm{Mg}$ in red and rose wines and $\mathrm{Ga}, \mathrm{Cd}$, and $\mathrm{Tl}$ in white wines produced recoveries $>120 \%$. The median values of $\mathrm{Ca}$ and $\mathrm{Fe}$ were consistent with the data from European viticulture areas and South Africa (Coetzee et al. 2005, Verbeke et al. 2009). The iron contents of red and white wines were also in agreement with data observed elsewhere (Simsek et al. 2008). The median values of $\mathrm{Na}$ and $\mathrm{Mg}$ contents were slightly greater than European wines, although the minimum-maximum ranges were consistent, and median levels were consistent with the Argentinean and Spanish wines. K levels in Turkish wines were lower than the levels in European wines but consistent with Argentinean wines (Fabani et al. 2010, Gonzalves et al. 2009, Verbeke et al. 2009). The minor elements were similar to those in literature. However, $\mathrm{Pb}, \mathrm{Cd}$, and $\mathrm{Cu}$ levels were lower than the data observed elsewhere (Simsek et al. 2008). According to the OIV maximum acceptable limits of elements in wine, one white wine sample (Narince variety from the Tokat region) exceeded the $\mathrm{Cu}$ limit $(1 \mathrm{mg} / \mathrm{L})$. The samples were below the OIV limits for $\mathrm{Zn}(5 \mathrm{mg} / \mathrm{L})$ and $\mathrm{Pb}(0.15 \mathrm{mg} / \mathrm{L})$.

The PCA model of all data showed that white and red wines were clearly separated from each other (score plot not shown). In the classification of wine samples, the white and red wines were studied separately in PLS-DA to show more clearly the separation among different red and white wine samples.

Regional discrimination. The PLS-DA models were developed by defining classes of wines with respect to the vineyard location. PLS-DA is a special extension of PLS regression and is used to find different classes of observations by using the information given in a $\mathrm{X}$ data matrix (n observations and $\mathrm{z}$ quality variables) and a $\mathrm{Y}$ matrix, which is a user-defined matrix of dummy variables representing the class of observations. In PLS-DA, among-classes variation is maximized against within-classes variation so that cluster of similar observations becomes apparent (Berruetaa et al. 2007).

The PLS-DA model for the discrimination of red and rosé wines according to geographic region was developed with eight variables defined by the VIP feature of the Simca software: $\mathrm{Sr}, \mathrm{Ni}, \mathrm{Ca}, \mathrm{Cu}, \mathrm{Li}, \mathrm{Pb}, \mathrm{B}$, and $\mathrm{Al}$. The classes were established for Elazı ğ and Diyarbakır as class 1 (nine observations), Denizli as class 2 (28 observations), and Izmir, Bozcaada, Manisa, and Thrace as class 3 (13 observations). Wines from central Anatolia (Ankara, Cappadocia [Kapadokya], and Tokat) appeared very scattered within the control ellipse and failed to form a cluster; consequently, the red wines of this region were not included in class models. The model with two principal components produced a regression coefficient of $\mathrm{Y}$ matrix $\left(\mathrm{R}_{\mathrm{Y}}^{2}\right)$ of 0.451 and a prediction coefficient $\left(\mathrm{Q}^{2}\right)$ of 0.275 (Figure 2A). The wine samples in the validation set were tested by the probability of the sample belonging to the model with a value $>10 \%$ (Simca-P). All wines in the prediction set were correctly classified by the developed calibration model. Red wines of grapes cultivated in western Turkey (Izmir, Bozcaada, Manisa, and Thrace) could clearly be discriminated from those in eastern Turkey (Elazığ and Diyarbakır). The wines from western Anatolia had higher Pb levels than the wines from the east, which may be related to the growing industrial development of western Turkey. According to one study, the major source of lead contamination in table wines is the vinification process (Almeida and Vasconcelos 2003). $\mathrm{Pb}$ can also originate from environmental factors such as soil contamination, atmospheric pollution, and fungicidal treatment (Volpe et al. 2009). In our study, the wine samples were from different producers. Regardless of producer, the wines of western regions such as Izmir, Denizli, Manisa, and Thrace had higher $\mathrm{Pb}$ levels than the wines of other regions, but still had less than the legal limit set by the OIV $(0.15 \mathrm{mg} / \mathrm{L})$.

The PLS-DA model for the discrimination of white wines according to geographic region was developed with eight variables ( $\mathrm{Sr}, \mathrm{Ni}, \mathrm{Li}, \mathrm{Mg}, \mathrm{Ba}, \mathrm{Pb}, \mathrm{Co}$, and $\mathrm{Al})$. The model with two principal components produced a regression coefficient of 


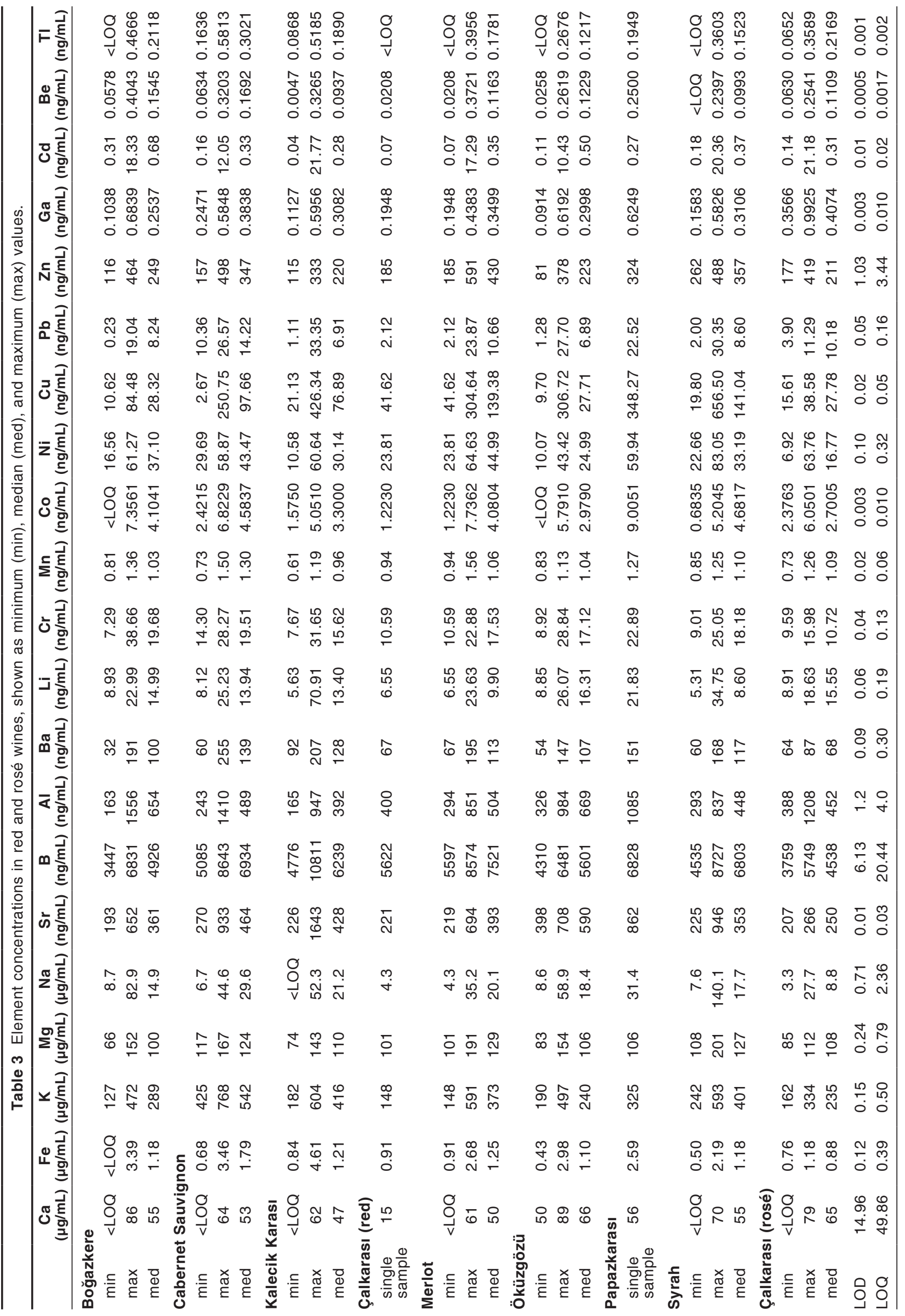




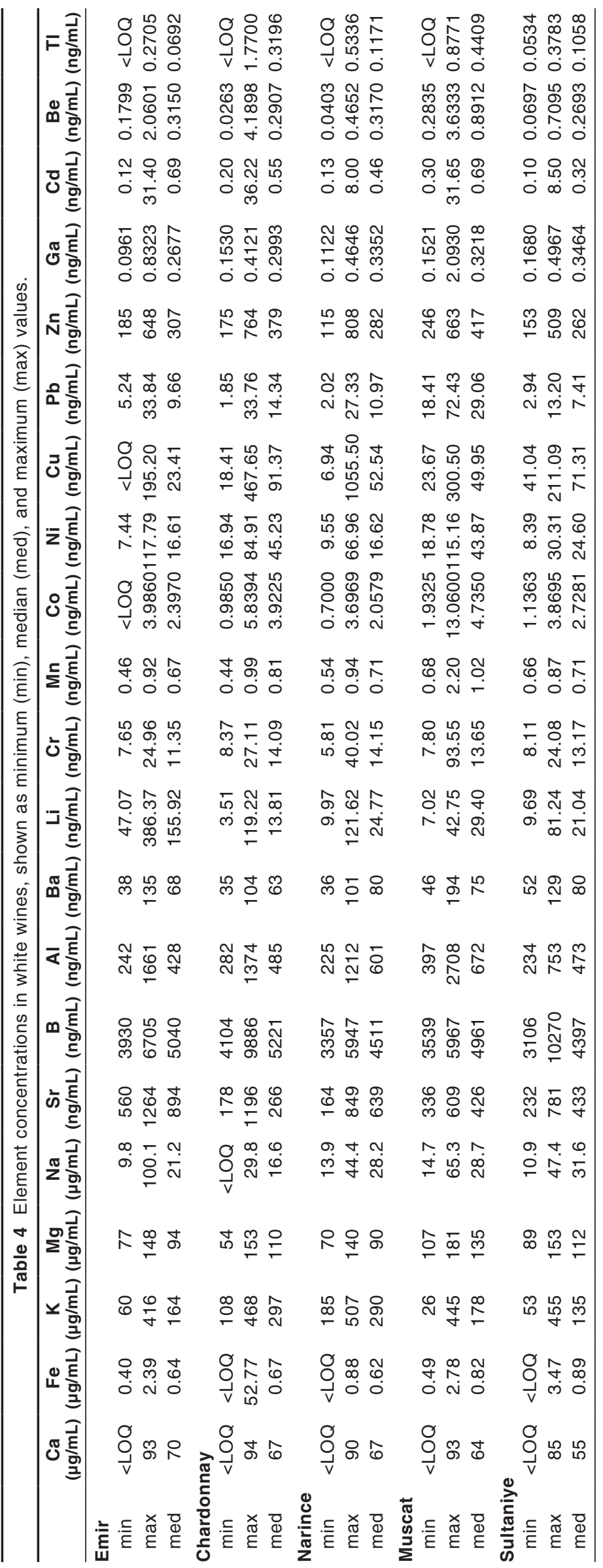

$\mathrm{Y}$ matrix $\left(\mathrm{R}_{\mathrm{Y}}^{2}\right) 0.619$ and a prediction coefficient $\left(\mathrm{Q}^{2}\right)$ of 0.372 (Figure 2B). The regional classes were established for Cappadocia and Tokat wines as class 1 (13 observations) and for Denizli, Izmir, Manisa, and Thrace wines as class 2 (24 observations). Cappadocia and Manisa wines were the richest in $\mathrm{Sr}$ and $\mathrm{Li}$ contents, despite their different classes. Izmir and Thrace wines were rich in $\mathrm{Pb}$, $\mathrm{Co}, \mathrm{Al}$, and Ni contents. Denizli wines were poor in $\mathrm{Sr}$, $\mathrm{Li}, \mathrm{Ba}$, and $\mathrm{Pb}$ contents. The concentrations of natural minerals such as $\mathrm{Ba}, \mathrm{B}, \mathrm{Li}, \mathrm{Al}$, and $\mathrm{Sr}$ do not depend on agricultural and processing activities, and they can play role on the regional discrimination of wine samples. For this study, it was recognized that the farther the distances among the vine growing regions, the better the discrimination. Similar results were reported elsewhere (Capron et al. 2007).

Varietal discrimination. Varietal discrimination was investigated through PLS-DA and HCA. The classes were
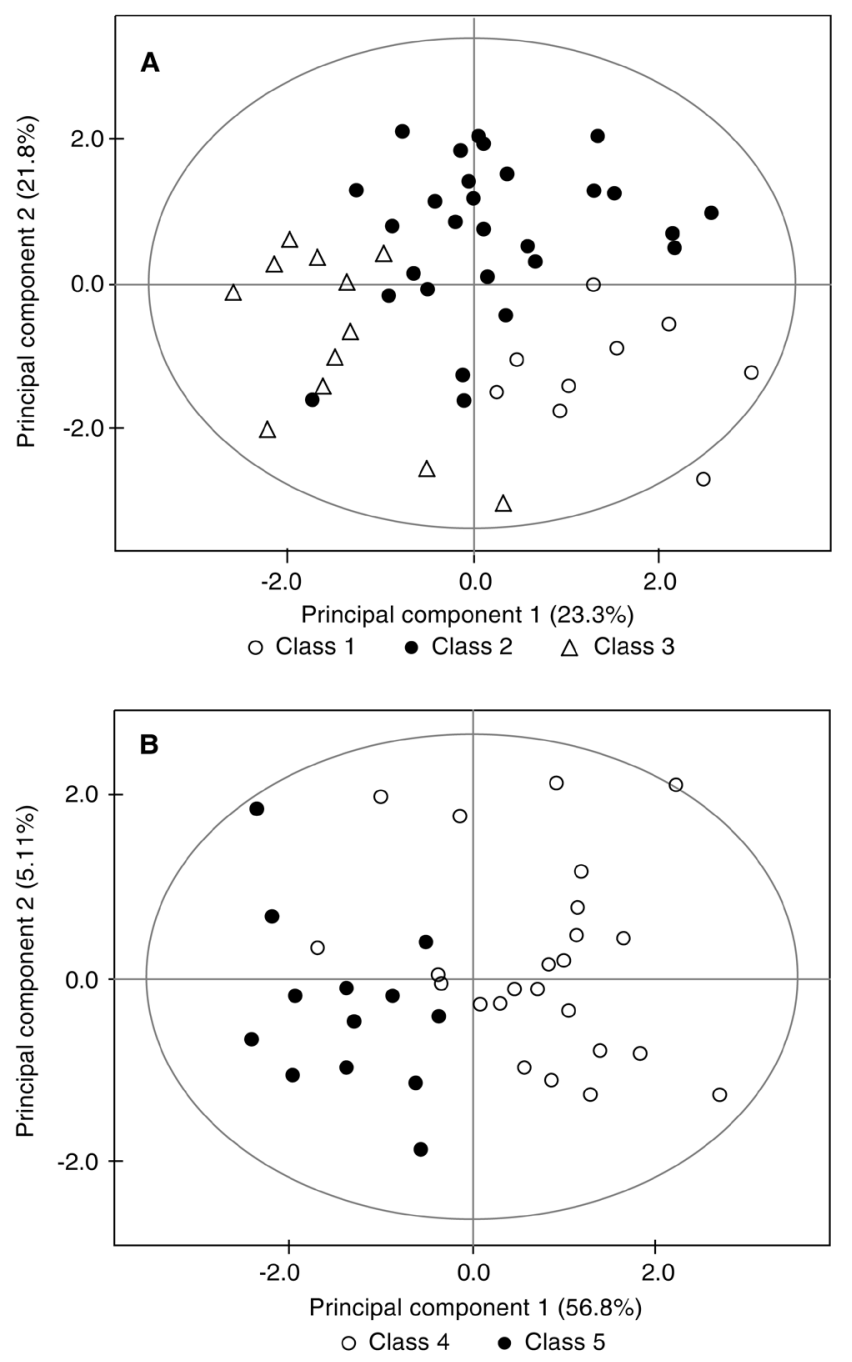

Figure 2 The PLS-DA score plots of red-rosé (A) and white (B) wines based on mineral content discriminated according to geographical region: (A) Class 1: Elazığ-Diyarbakır, Class 2: Denizli, Class 3: Thrace-Bozcaada-Izmir-Manisa; (B) Class 4: Thrace-Izmir-ManisaDenizli, Class 5: Cappadocia-Tokat. The explained variation by each component is given in parenthesis on the axes. 
defined with respect to grape variety. For the red wines, a two-component PLS-DA model was developed with $\mathrm{Mn}, \mathrm{Cu}$, $\mathrm{B}, \mathrm{Ca}, \mathrm{Al}, \mathrm{Ba}, \mathrm{Li}, \mathrm{K}$, and $\mathrm{Zn}\left(\mathrm{R}_{\mathrm{Y}}^{2}=0.191, \mathrm{Q}^{2}=0.116\right)$. The elements were defined by the VIP feature of Simca software as the significant variables in the discrimination. Results indicated that the wines of two native varieties, Boğazkere and Öküzgözü, could be discriminated from the other varieties based on their higher $\mathrm{Ca}$ and lower $\mathrm{B}$ and $\mathrm{Cu}$ levels (Figure $3 \mathrm{~A})$. The majority of these native wines were from the eastern regions (Diyarbakır and Elazığ). There were also five wine samples of Boğazkere and Öküzgözü from central Anatolia (Cappadocia and Tokat). These wines were also clustered among other Boğazkere and Öküzgözü samples, despite the
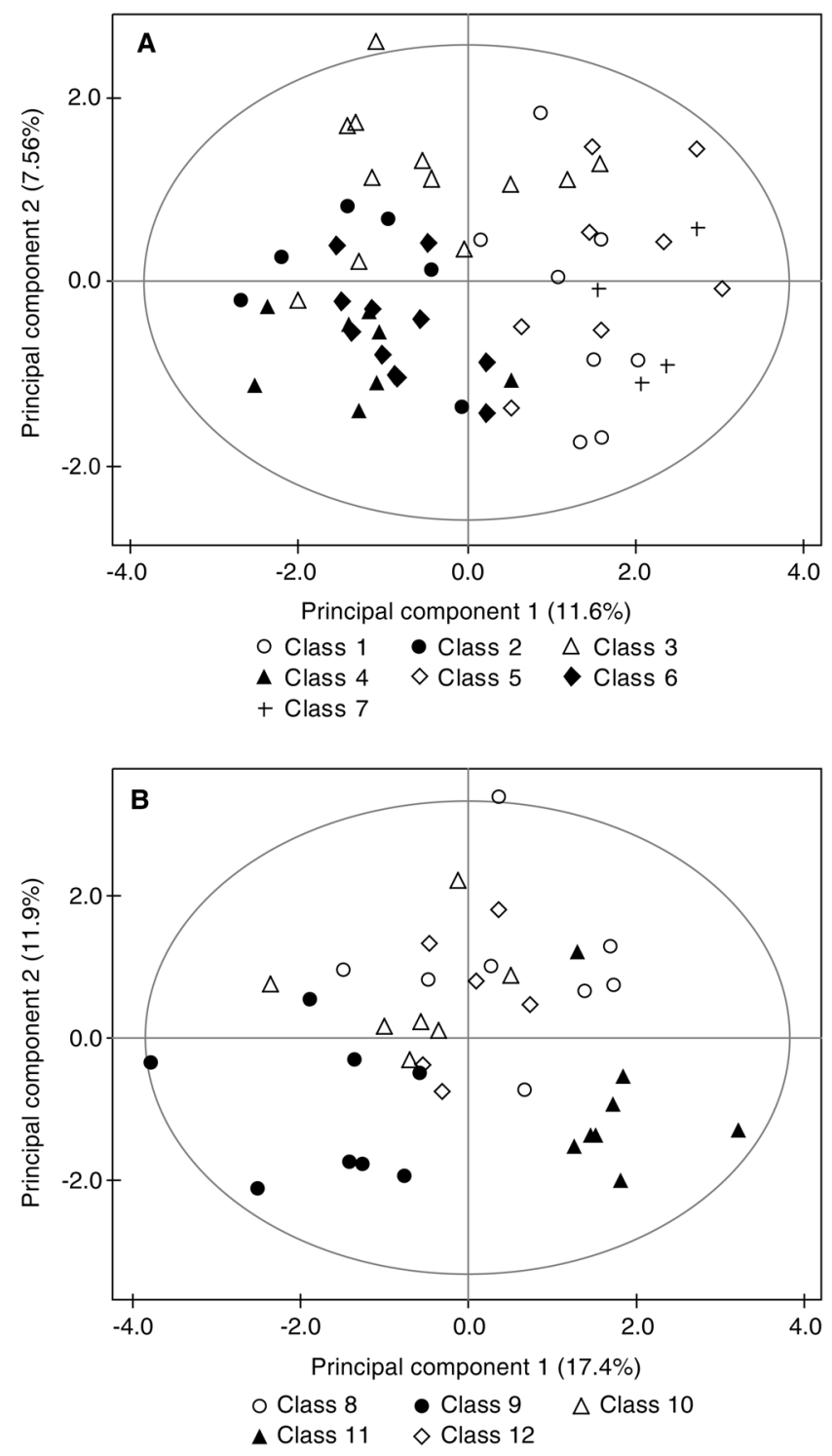

Figure 3 The PLS-DA score plots of red-rosé wines (A) and white wines (B) based on mineral content discriminated according to grape variety: (A) Class 1: Boğazkere, Class 2: Cabernet Sauvignon, Class 3: Kalecik Karası, Class 4: Merlot, Class 5: Öküzgözü, Class 6: Syrah, Class 7: Çalkarası; (B) Class 8: Chardonnay, Class 9: Emir, Class 10: Narince, Class 11: Muscat, Class 12: Sultaniye. The explained variation by each component is given in parenthesis on the axes. regional differences. For the white wines, a two-component PLS-DA model was developed with $\mathrm{Co}, \mathrm{Cu}, \mathrm{Li}, \mathrm{K}, \mathrm{Pb}, \mathrm{Sr}$, $\mathrm{Mg}, \mathrm{Mn}$, and $\mathrm{Na}\left(\mathrm{R}_{\mathrm{Y}}^{2}=0.293, \mathrm{Q}^{2}=0.191\right)$. The discrimination between Emir and Muscat white wines was considered to be based on the higher $\mathrm{Li}$ and $\mathrm{Sr}$ and lower $\mathrm{Cu}$ levels of Emir wines and higher $\mathrm{Pb}, \mathrm{Co}$, and $\mathrm{Mn}$ levels of Muscat wines (Figure 3B). Emir is a native grape variety in central Anatolia, whereas Muscat is grown mostly in western Anatolia. Western Turkey is a highly industrialized area, which may help to explain the relatively higher $\mathrm{Pb}$ content of Muscat wines from Izmir, Manisa, Denizli, and Thrace. Details of PLS-DA models for red and white wines and the membership probabilities of samples in the validation sets are given in Supplemental Tables 1 and 2 .

Hierarchical cluster analysis was successful in showing differences between some red and white wines. For red wines, native Öküzgözü wines were discriminated from the wines of Syrah and Cabernet Sauvignon varieties (Figure 4). The Euclidean technique and ward linkage method was preferred. The models were established using the variables used in the
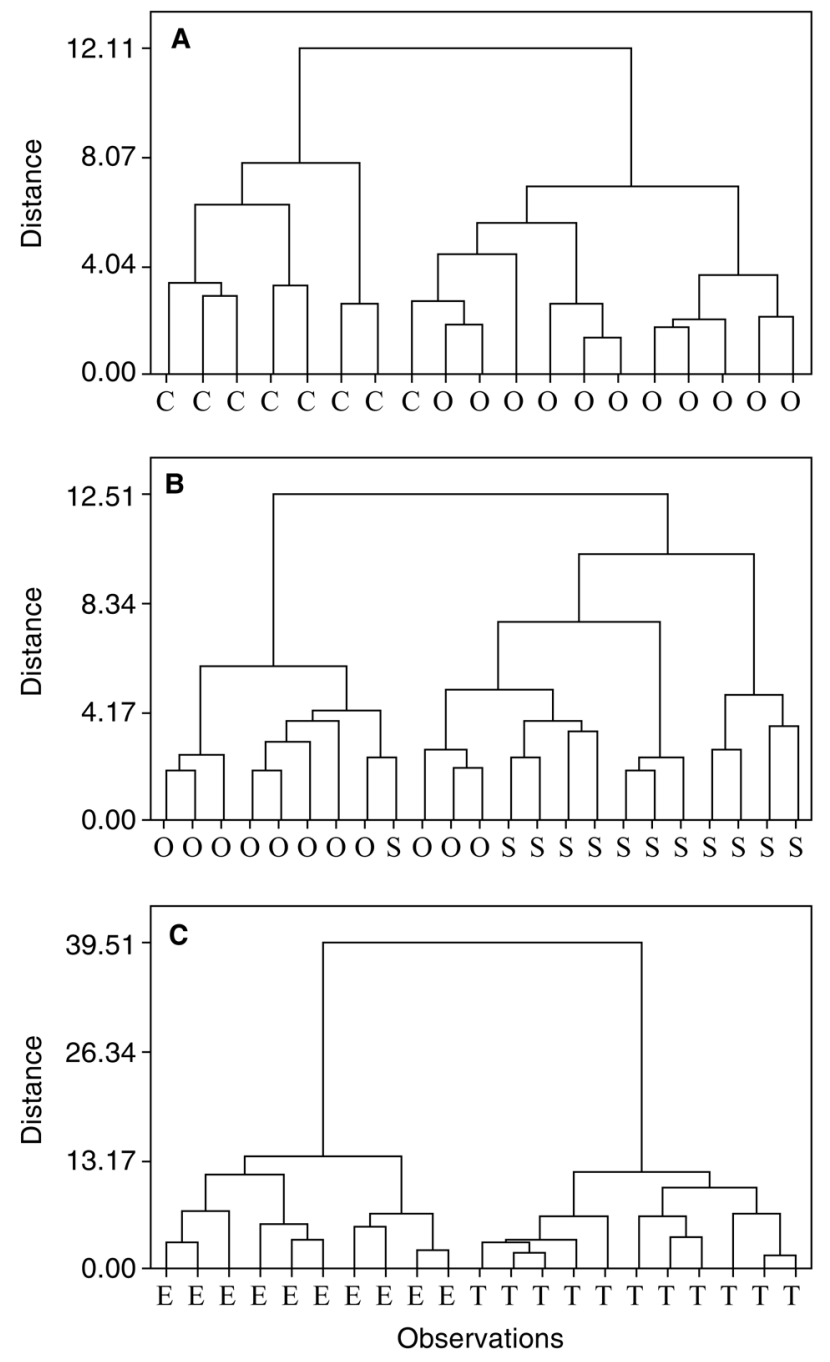

Figure 4 Dendrograms of some red and white wines based on mineral contents: A: Öküzgözü $(O)$ and Cabernet Sauvignon $(C)$ wines; B: Öküzgözü $(O)$ and Syrah $(S)$ wines; C: Emir (E) and Muscat $(T)$ wines. 
PLS-DA model for varietal discrimination of red wines. One Cabernet Sauvignon wine from the 2008 harvest year was clustered with the Öküzgözü variety (Figure 4A), and three Öküzgözü wines from 2009 harvest year were clustered within the Syrah group (Figure 4B). There was also one Syrah wine from 2006 harvest year located in the Öküzgözü cluster. For white wines, Muscat and Emir could be discriminated using the same variables used in the PLS-DA model of white wines. All the samples belonging to the two varieties were clustered in their own groups (Figure 4C).

\section{Discussion}

The elemental profiles of red and white wines differed from each other with higher levels of $\mathrm{K}$ and $\mathrm{Ba}$ and lower levels of $\mathrm{Li}$ in red wines. The slightly higher levels of minerals in red wines can be explained by the prolonged leaching of minerals from the grape during maceration (Coetzee et al. 2005, Martin et al. 2012). Statistical analyses were performed separately on the red-rosé wines and white wines.

The information for the wine samples in this study was based on the data given on the wine bottles. It should be emphasized that these commercial samples were produced under different conditions. The expected variability in their chemical composition due to the different vineyards, harvest year, or grape varieties might also be affected by the different production practices. Despite these various sources of variations, the wines of some varieties and some geographical origins separated themselves from others.

A limited number of samples made it difficult to fully evaluate the effect of variety and vineyard location. This was especially the case for the wines belonging to certain grape varieties, which were grown in one particular region only, such as Emir wines produced from Emir grapes of Cappadocia. Therefore, a confounding conclusion from the interpretation of data for regional and varietal classes could occur. In other words, it is not possible to be certain whether the differences of this wine are due to geographical origin or grape variety, with the available samples.

The performance of mineral content was also investigated for the discrimination of wine samples according to harvest years. The results of PCA indicated that the mineral profile of wine samples were independent of their vintage. Similar results have been reported (Martin et al. 2012).

\section{Conclusion}

The monovarietal wines produced from the native and nonnative grape varieties grown in Turkey were characterized in terms of elemental composition. The wine samples were classified with multivariate statistical techniques to show that the geography - where the grape was grown-determines the presence of certain minerals in wines. Regional discrimination was possible between the western and eastern wine-producing areas with the discriminating power of minerals such as $\mathrm{Sr}, \mathrm{Li}$, $\mathrm{Ni}, \mathrm{Ba}, \mathrm{B}, \mathrm{Pb}, \mathrm{Ca}$, and $\mathrm{Al}$. The wines of vineyards in western Turkey, where industrialization is high, discriminated themselves with relatively higher amounts of $\mathrm{Pb}$, but still less than the allowable maximum level. Wines of some native Turkish grape varieties, such as Öküzgözü and Emir, had distinctive characteristics compared with the other wine samples.

\section{Literature Cited}

Almeida, C.M.R., and M.T.S.D. Vasconcelos. 2003. Lead contamination in Portuguese red wines from the Douro region: From the vineyard to the final product. J. Agric. Food Chem. 51:3012-3023.

Angus, N.S., T.J. O’Keeffe, K.R. Stuart, and G.M. Miskelly. 2006. Regional classification of New Zealand red wines using inductivelycoupled plasma-mass spectrometry (ICP-MS). Aust. J. Grape Wine Res. 12:170-176.

Berruetaa, L.A., R.M. Alonso-Salcesa, and K. Heberger. 2007. Supervised pattern recognition in food analysis. J. Chromatogr., A 1158:196-214.

Capron, X., J. Smeyers-Verbeke, and D.L. Massart. 2007. Multivariate determination of the geographical origin of wines from four different countries. Food Chem. 101:1585-1597.

Castro, I., J.P. Martin, J.M. Ortiz, and O. Pinto-Carnide. 2011. Varietal discrimination and genetic relationships of Vitis vinifera L. cultivars from two major controlled appellation (DOC) regions in Portugal. Sci. Hortic.-Amsterdam 127:507-514.

Coetzee, P.P., F.E. Steffens, R.J. Eiselen, O.P. Augustyn, L. Balcaen, and F. Vanhaecke. 2005. Multi-element analysis of South African wines by ICP-MS and their classification according to geographical origin. J. Agric. Food Chem. 53:5060-5066.

Eriksson, L., E. Johanson, N.K. Wold, and S. Wold. 2001. Multi- and Megavariate Data Analysis: Principals and Applications. Umetrics AB, Umea, Sweden.

Etievant, P., S. Pascal, J.C. Bouvier, P. Symonds, and A. Bertrand. 1988. Varietal and geographic classification of French red wines in terms of elements, amino acids and aromatic alcohols. J. Sci. Food Agric. 45:25-41.

Fabani, M.P., R.C. Arrúa, F. Vázquez, M.P. Diaz, M.V. Baroni, and D.A. Wunderlin. 2010. Evaluation of elemental profile coupled to chemometrics to assess the geographical origin of Argentinean wines. Food Chem. 119:372-379.

Gomez, M.D.M.C, I. Feldmann, N. Jakubowski, and J.T. Andersson. 2004. Classification of German white wines with certified brand of origin by multielement quantitation and pattern recognition techniques. J. Agric. Food Chem. 52:2962-2974.

Gonzalves, A., S. Armenta, A. Pastor, and M. Guardia. 2008. Searching the most appropriate sample pretreatment for the elemental analysis of wines by inductively coupled plasma-based techniques. J. Agric. Food Chem. 56:4943-4954.

Gonzalves, A., A. Llorens, M.L. Cervera, S. Armenta, and M. Guardia. 2009. Elemental fingerprint of wines from the protected designation of origin Valencia. Food Chem. 112:26-34.

Grindlay, G., J. Mora, S. Maestre, and L. Gras. 2008. Application of a microwave-based desolvation system for multi-elemental analysis of wine by inductively coupled plasma based techniques. Anal. Chim. Acta 629:24-37.

Kment, P., M. Mihaljevic, V. Ettler, O. Sebek, L. Strnad, and L. Rohlova. 2005. Differentiation of Czech wines using multielement composition - A comparison with vineyard soil. Food Chem. 91:157-165.

Marengo, E., and M. Aceto. 2003. Statistical investigation of the differences in the distribution of metals in Nebbiolo-based wines. Food Chem. 81:621-630.

Marini, F., R. Bucci, A.L. Magri, and A.D. Magri. 2006. Authentication of Italian CDO wines by class-modeling techniques. Chemometr. Intell. Lab. 84:164-171. 
Martin, A.E., J. Watling, and G.S. Lee. 2012. The multi-element determination and regional discrimination of Australian wines. Food Chem. 133:1081-1089.

Martinez-Carrasco, L., M. Brugarolas, and A. Martinez-Poveda. 2005. Quality wines and wines protected by a designation of origin: Identifying their consumption determinants. J. Wine Res. 16:213-232.

Moreno, I.M., D.G. Weller, V. Gutierrez, M. Marino, A.M. Camean, A.G. Gonzalez, and A. Hardisson. 2007. Differentiation of two Canary DO red wines according to their metal content from inductively coupled plasma optical emission spectrometry and graphite furnace atomic absorption spectrometry by using probabilistic neural networks. Talanta 72:263-268.

OIV. 2013. Statistical report on world vitiviniculture. International Organisation of Vine and Wine, Intergovernmental Organisation, Paris.

Saavedra, J., J. Fuentealba, L. Yáñez, M. Bravo, W. Quiroz, G. Lukacsy, and J.M. Carot. 2011. Chemometric approaches for the zoning of Pinot Noir wines from the Casablanca Valley, Chile. Food Chem. 127:1842-1847

Simsek, O., G.S. Senol, and S.D Velioglu. 2008. Trakya bolgesinde uretilen sarapların agir metal iceriklerinin belirlenmesi uzerine bir arastirma. In the Abstract Book of Türkiye 10. Gida Kongresi (National Food Congress), pp. 223-226. Erzurum, Turkey.

Skurikhin, I.M. 1993. Methods of analysis for toxic elements in foods. Part IV. General method of ashing for determination of toxic elements. J. AOAC 76:257-262.
Sperkova, J.S., and M. Suchanek. 2005. Multivariate classification of wines from different Bohemian regions (Czech Republic). Food Chem. 93:659-663.

Thiel, G., G. Geisler, I. Blechschmidt, and K. Danzer. 2004. Determination of trace elements in wines and classification according to their provenance. Anal. Bioanal. Chem. 378:1630-1636.

Trujillo, J.P.P., J.E. Conde, M.L.P. Pont, J. Camara, and J.C. Marques. 2011. Content in metallic ions of wines from the Madeira and Azores archipelagos. Food Chem. 124:533-537.

Verbeke, J.S., H. Jager, S. Lanteri, P. Brereton, E. Jamin, C.F. Hassek, M. Forina, and U. Römisch. 2009. Characterization and determination of the geographical origin of wines. Part II. Descriptive and inductive univariate statistics. Eur. Food Res. Technol. 230:15-29.

Volpe, M.G, F. La Cara, F. Volpe, A. De Mattia, V. Serino, F. Petitto, C. Zavalloni, F. Limone, R. Pellecchia, P.P. De Prisco, and M. Di Stasio. 2009. Heavy metal uptake in the enological food chain. Food Chem. 117:553-560

Zou, J.F., Z.X. Peng, H.J. Du, C.Q. Duan, M.J. Reeves, and Q.H. Pan. 2012. Elemental patterns of wines, grapes, and vineyard soils from Chinese wine-producing regions and their association. Am. J. Enol. Vitic. 63:232-240 